\title{
TRADE LIBERALIZATION IN A JOINT SPATIAL INTER-TEMPORAL TRADE MODEL
}

\author{
HUI HUANG \\ JOHN WHALLEY \\ SHUNMING ZHANG
}

CESIFO WORKING PAPER NO. 1463

CATEGORY 7: TRADE POLICY

MAY 2005

Presented at CESifo Area Conference on Global ECONOMy, JANUARy 2004

\footnotetext{
An electronic version of the paper may be downloaded

- from the SSRN website:

http://SSRN.com/abstract $=713301$

- from the CESifo website:

www.CESifo.de
} 


\title{
TRADE LIBERALIZATION IN A JOINT SPATIAL INTER-TEMPORAL TRADE MODEL
}

\begin{abstract}
This paper considers liberalization of trade in both inter-temporal intermediation services and goods in a joint spatial-inter-temporal trade model. Joint multi-commodity spatial intertemporal models are not (to our knowledge) used in the trade literature as general comparative statics results are unavailable and (in the presence of incomplete markets) existence can also be an issue. Here we use numerical simulation methods. We first consider world with service trade autarky in which there is no domestic intermediation service provision, and service trade liberalization involves costless inter-temporal intermediation provided by foreign service providers. This simple treatment allows us to model service trade liberalization as removing period by period budget constraints for domestic consumers. In such a world, if nonzero tariffs apply to spatial trade we present an example showing how service trade liberalization can be welfare worsening. One implication is that negotiations on services in the WTO General Agreement on Trade in Services (GATS) need not be welfare improving if there are also ongoing tariff negotiations. We then expand the model to capture a more complex world where costly intermediation services can be provided by both withincountry and foreign providers. We again illustrate how services liberalization can be welfare worsening. We finally discuss whether welfare worsening service trade liberalization is likely in a real-world situation of highly restricted services trade and considerably more open goods trade, and when services trade are around $1 / 3$ of total goods and services trade as is often claimed from available global service trade data.
\end{abstract}

JEL Code: F00, F11.

Hui Huang
University of Western Ontario
Department of Economics
Social Science Centre
London, Ontario, N6A 5C2
Canada
hhuang@uwo.ca

Shunming Zhang

University of Western Ontario

Department of Economics

Social Science Centre

London, Ontario N6A 5C2

Canada

szhang@uwo.ca

\author{
John Whalley \\ University of Western Ontario \\ Department of Economics \\ Social Science Centre \\ London, Ontario, N6A 5C2 \\ Canada \\ jwhalley@uwo.ca
}




\section{Introduction}

Most of the policy literature on multilateral services trade liberalization under the WTO General Agreement on Trade in Services (GATS) implicitly assumes that such liberalization is globally efficiency improving. Service liberalization is seen as extending the coverage of existing WTO liberalization beyond trade in goods to also cover such service areas as banking, insurance, telecoms, and transportation. As such, service trade liberalization is implicitly accepted as globally desirable. ${ }^{1}$

Some existing literature already suggests that such liberalization need not be welfare improving but does not explicitly consider models with joint spatial and inter-temporal trade. ${ }^{2}$ Here we go further and treat service-trade liberalization as applying to intermediation services through time (banking) in a joint spatial - inter-temporal model. A similar analysis can likely be applied to liberalization of trade in other intermediation services such as across risk (insurance) and space (transportation, telecoms).

We consider liberalization of service trade of this type in a simple general equilibrium model with both inter-temporal and spatial trade. In a series of 2 country, 2 good, and 2 period numerical simulation analyses, we consider cases in which tariffs distort trade within periods both before and after service liberalization. Initially there is inter-temporal autarky (no inter-temporal intermediation) in services, which, for simplicity, we characterize as no domestic provision of intermediation services. Using this framework we are able to separately consider both tariff liberalization (removing or reducing tariffs) and services liberalization which allows for foreign providers to enter domestic markets and remove inter-temporal budget constraints. We are thus able to consider services liberalization in

\footnotetext{
${ }^{1}$ See Hindley and Smith (1984), McCulloch (1990), Hoekman (1995) and Dee and Hanslow (2001) although also see Ryan (1990) and Whalley (2003) for further work which qualifies this view.

${ }^{2}$ Chia and Whalley (1995) discuss a single time dated commodity inter-temporal trade model with costly intermediation services over time, and with both domestic and foreign service providers. They report a two-country example where international liberalization of trade in banking services which allows both domestic and foreign providers to operate in all markets can be welfare worsening. This result occurs because with transaction costs the two fundamental theorems need not hold (Foley (1970)). Also, the literature on piecemeal policy reform (Hatta 1977) discusses the relative desirability of radial reductions in tariff rates on all commodities relative to more concentrated and larger reductions of tariff for only a subset of commodities, and this literature also seemingly applies to services liberalization in the presence of restricted goods trade. Public finance literature discusses the related issue of the welfare gains from reduced variance in tax (including trade tax) rates (see Harberger 1964).
} 
the presence of tariffs, tariff liberalization in the presence of service trade restrictions, and joint liberalization of both goods and services.

We explore whether services liberalization need be welfare improving in numerical examples. Initially, we consider a simple world in which there is no domestic provision of intermediation services but liberalization permits foreign entry of costless service providers who, in effect, remove period by period budget constraints. This is in the spirit of the literature on incomplete markets (Hart (1975), Duffie and Shafer (1985), Magill and Shafer (1990)), but we do not explicitly consider uncertainty and we concentrate on numerical solution and comparative static analyses rather than on existence. We then consider an extension to this model with costly intermediation and with both domestic and foreign service providers both before and after liberalization. These two service providers have differential costs. In this model, service trade liberalization typically increases the amount of intermediation; inter-temporal intermediation services are used initially in both countries but after liberalization are provided in both countries by the relatively more efficient domestic service provider.

To explore the possibility of perverse service liberalization outcomes, we calibrate the joint inter-temporal and spatial trade models we develop to stylized (rather than real) equilibrium data sets for 2 good 2 country 2 time period cases, and consider liberalization of goods trade, services trade and both. We report experiments where with preexisting tariffs services liberalization can be welfare worsening. We then assess for which portions of the parameter space for the formalizations we explore perverse outcomes are likely to occur through sensitivity analysis.

In a final section we discuss how our analysis could relate to the contemporary global economy where services trade is perhaps $\frac{1}{3}$ of total goods and services trade, and services are more heavily restricted than goods, albeit by regulatory devices more so than by tariffs. The severity of service trade restrictions in this case seemingly makes it more likely that services liberalization may be welfare improving, but this remains a judgmentally based evaluation rather than a clearly established result.

General results are probably unattainable for the simulation structure we explore numerically here, but the mere possibility that adding services liberalization to conventional goods liberalization in the presence of goods trade restrictions can be welfare worsening is important for the ways in which GATS and services liberalization in the WTO are currently 
discussed. Until such time that goods trade is free of restrictions the implication is that services trade liberalization in the GATS needs to be shown to be welfare improving in particular cases before it can be strongly advocated. 


\section{A Simple Multi-Country Model of Spatial and Inter-Temporal Trade}

To explore whether services trade liberalization under the framework of the GATS can be welfare worsening in particular cases for joint spatial and inter-temporal trade models, we use a simple 2 period $(t=0,1) 2$ country $(i=1,2) 2 \operatorname{good}(l=1,2)$ pure exchange model. In this, each country has a single representative consumer, each with endowments of the two goods in each period $\left(E_{i l}^{t} ; t=0,1, i=1,2, l=1,2\right)$. For simplicity, a time-additive utility function is used of the form

$$
U_{i}=\sum_{t=0}^{1} \frac{1}{\left(1+\rho_{i}\right)^{t}} u_{i}^{t}\left(X_{i 1}^{t}, X_{i 2}^{t}\right)=u_{i}^{0}\left(X_{i 1}^{0}, X_{i 2}^{0}\right)+\frac{1}{1+\rho_{i}} u_{i}^{1}\left(X_{i 1}^{1}, X_{i 2}^{1}\right), \quad i=1,2
$$

where $u_{i}^{t}\left(X_{i 1}^{t}, X_{i 2}^{t}\right)=\left[X_{i 1}^{t}\right]^{\alpha_{i 1}^{t}}\left[X_{i 2}^{t}\right]_{i 2}^{t}$ for $t=0,1$ and $i=1,2$. This can be represented more explicitly in the Cobb-Douglas case as

$$
U_{i}=\left[X_{i 1}^{0}\right]^{\alpha_{i 1}^{0}}\left[X_{i 2}^{0}\right]^{\alpha_{i 2}^{0}}+\frac{1}{1+\rho_{i}}\left[X_{i 1}^{1}\right]^{\alpha_{i 1}^{1}}\left[X_{i 2}^{1}\right]^{\alpha_{i 2}^{1}}, \quad i=1,2
$$

where $\rho_{i}$ is inter-temporal discount factor for individual $i, X_{i l}^{t}$ denotes consumption of good $l$ for country $i$ at date $t$, and $\alpha_{i l}^{t}$ is share parameter for good $l$ for country $i$ at date $t$ $\left(\sum_{l=1}^{2} \alpha_{i l}^{t}=1\right)$.

We also later consider a single representative consumer for each country with a timeadditive CES utility function of the form (1) where

$$
u_{i}^{t}\left(X_{i 1}^{t}, X_{i 2}^{t}\right)=\left\{\left[\alpha_{i 1}^{t}\right]^{\frac{1}{\sigma_{i}^{t}}}\left[X_{i 1}^{t}\right]^{\frac{\sigma_{i}^{t}-1}{\sigma_{i}^{t}}}+\left[\alpha_{i 2}^{t}\right]^{\frac{1}{\sigma_{i}^{t}}}\left[X_{i 2}^{t}\right]^{\frac{\sigma_{i}^{t}-1}{\sigma_{i}^{t}}}\right\}^{\frac{\sigma_{i}^{t}}{\sigma_{i}^{t}-1}}
$$

for $t=0,1$ and $i=1,2$, which can be written more explicitly as

$$
\begin{aligned}
& U_{i}=\left\{\left[\alpha_{i 1}^{0}\right]^{\frac{1}{\sigma_{i}^{0}}}\left[X_{i 1}^{0}\right]^{\frac{\sigma_{i}^{0}-1}{\sigma_{i}^{0}}}+\left[\alpha_{i 2}^{0}\right]^{\frac{1}{\sigma_{i}^{0}}}\left[X_{i 2}^{0}\right]^{\frac{\sigma_{i}^{0}-1}{\sigma_{i}^{0}}}\right\}^{\frac{\sigma_{i}^{0}}{\sigma_{i}^{0}-1}} \\
&+\frac{1}{1+\rho_{i}}\left\{\left[\alpha_{i 1}^{1}\right]^{\frac{1}{\sigma_{i}^{1}}}\left[X_{i 1}^{1}\right]^{\frac{\sigma_{i}^{1}-1}{\sigma_{i}^{1}}}+\left[\alpha_{i 2}^{1}\right]^{\frac{1}{\sigma_{i}^{1}}}\left[X_{i 2}^{1}\right]^{\frac{\sigma_{i}^{1}-1}{\sigma_{i}^{1}}}\right\}^{\frac{\sigma_{i}^{1}}{\sigma_{i}^{1}-1}}, \quad i=1,2
\end{aligned}
$$

where $\sigma_{i}^{t}$ is the constant elasticity of substitution between goods in consumption for country $i$ in periof $t$.

For any good $l$, in any period $t$, we can define the seller's (net of tariff) price as $P_{l}^{t}$ and we then allow each country $i$ to impose tariffs at rate $T_{i l}^{t}$ on each imported good $l$ (i.e. if 
$X_{i l}^{t} \geq E_{i l}^{t}$, then $T_{i l}^{t} \geq 0$ ). Tariffs are set to zero for any export $i$ (i.e. if $X_{i l}^{t} \leq E_{i l}^{t}$, then $T_{i l}^{t}=0$ ). Internal (gross of tariff) prices for good $l$ in country $i$ at date $t$ are thus

$$
P_{i l}^{t}=P_{l}^{t}\left(1+T_{i l}^{t}\right), \quad t=0,1, \quad i=1,2, \quad l=1,2 .
$$

These are also sellers prices of good $l$ in country $i$.

Tariff revenues collected in country $i$ in period $t$ are

$$
R_{i}^{t}=\sum_{l=1}^{2} P_{l}^{t} T_{i l}^{t}\left(X_{i l}^{t}-E_{i l}^{t}\right)^{+}, \quad t=0,1, \quad i=1,2
$$

where $E_{i l}^{t}$ denotes the initial endowment of good $l$ for country $i$, and the total income of country $i$ in period $t$ is given by

$$
I_{i}^{t}=\sum_{l=1}^{2} P_{i l}^{t} E_{i l}^{t}+R_{i}^{t}, \quad t=0,1, \quad i=1,2 .
$$

To simplify matters, we initially assume that there is service autarky and that in this case (and as a strong assumption) there no intermediation provided by domestic service providers. This is clearly an artificial construct (which we relax later) whose main virtue is simplicity. This enables us to appeal directly to relevant literature on multi-commodity inter-temporal models from Radner(1972), Hart (1975), Duffie and Shafer (1985), Werner (1985), Duffie (1987), Geanakopolos (1990), Magill and Shafer (1991), and Magill and Quinzii (1996) in analysing the effects of service liberalization in this simple way. We do this without the added complication of uncertainty which is central to this liberalization. Most of this literature is concerned with existence issues; our focus here is comparative statics. We assume for now (and also for further simplicity) that under free trade in services, intermediation services are provided costlessly by foreign banks. ${ }^{3}$

This means that in the autarky case, period by period budget constraints apply for each country $i$ and in each period $t$, i.e.

$$
\sum_{l=1}^{2} P_{i l}^{t} X_{i l}^{t}=I_{i}^{t}, \quad t=0,1, \quad i=1,2 .
$$

These imply that

$$
\sum_{l=1}^{2} P_{l}^{t}\left(1+T_{i l}^{t}\right) X_{i l}^{t}=\sum_{l=1}^{2} P_{l}^{t}\left(1+T_{i l}^{t}\right) E_{i l}^{t}+R_{i}^{t}, \quad t=0,1 ; \quad i=1,2 .
$$

\footnotetext{
${ }^{3}$ See the discussion of barriers to trade in intermediation services in practice in Chen and Schembri (2002), Francois and Schuknecht (2000), Kalirajan, McHuire, Nguyen and Schuele (2001), and Mattoo (1999).
} 
The combined budget constraint for country $i$ over the two periods is

$$
\sum_{t=0}^{1} \sum_{l=1}^{2} P_{i l}^{t} X_{i l}^{t}=\sum_{t=0}^{1} I_{i}^{t}, \quad i=1,2
$$

which implies

$$
\sum_{t=0}^{1} \sum_{l=1}^{2} P_{l}^{t}\left(1+T_{i l}^{t}\right) X_{i l}^{t}=\sum_{t=0}^{1} \sum_{l=1}^{2} P_{l}^{t}\left(1+T_{i l}^{t}\right) E_{i l}^{t}+\sum_{t=0}^{1} R_{i}^{t}, \quad i=1,2 .
$$

This simple treatment of services liberalization allows us to consider two different equilibria, one with period by period budget constraints, and the other only with across period budget constraints. Moving from period by period budget constraints to an across period budget constraint can be thought of as allowing for inter-temporal intermediation in consumption activities across periods where non previously occurred. The interpretation is that initially there is autarky in trade in intermediation services since none can be provided domestically. We then open up to international trade in intermediation services, which are costlessly provided, a simple form of trade liberalization in inter-temporal intermediation services. We can thus consider goods trade liberalization as a reduction in tariffs where no service liberalization occurs, or service liberalization where no tariff liberalization occurs. We can also consider services liberalization in a tariff-free world, and tariff liberalization in a world either with or without service restrictions. Finally, we can consider joint tariff and services liberalization.

This joint spatial inter-temporal economy can be thought of as one in which there are a series of spot markets in goods, and in the presence of services liberalization a system of asset markets which permit the transfer of income among spot markets in the sense first analyzed by Arrow (1964) and later by Hart (1975), Werner (1985), and Magill and Shafer (1991). 4 It contrasts with earlier inter-temporal equilibrium formalizations of a set of Arrow-Debreu contingent commodity markets as in Debreu (1959).

\footnotetext{
${ }^{4}$ Hart (1975) showed, with uncertainty and hence incomplete markets, an equilibrium may not exist, or an inefficient equilibrium may result. Werner (1985) discusses the general issue of existence for such economies; Magill and Shafer (1991) show among others results how in the certainty case the multi-commodity intertemporal equilibrium is equivalent to one in which an interest rate is endogenously determined and equals the ratio of the shadow prices of period by period budget constraints for each of the individuals in the economy.
} 
The two equilibria we consider for this structure can be stated as follows.

[Definition] General Equilibrium with Period by Period Budget Constraints

A general equilibrium for this economy with period by period budget constraints is characterized by a price system and consumption of goods by countries $\left(\left(P_{l}^{t}: t=0,1 ; l=\right.\right.$ $\left.1,2),\left(X_{i l}^{t}: t=0,1 ; i=1,2 ; l=1,2\right)\right)$ such that

[1] given $\left(P_{l}^{t} ; t=0,1, l=1,2\right)$, for $\mathrm{i}=1,2,\left(X_{i l}^{t} ; t=0,1, l=1,2\right)$ solve the utility maximization problem subject to the period by period budget constraints (7),

$$
\begin{array}{ll}
\max & U_{i}=u_{i}^{0}\left(X_{i 1}^{0}, X_{i 2}^{0}\right)+\frac{1}{1+\rho_{i}} u_{i}^{1}\left(X_{i 1}^{1}, X_{i 2}^{1}\right) \\
\text { s.t. } & \sum_{l=1}^{2} P_{l}^{t}\left(1+T_{i l}^{t}\right) X_{i l}^{t}=\sum_{l=1}^{2} P_{l}^{t}\left(1+T_{i l}^{t}\right) E_{i l}^{t}+R_{i}^{t}, \quad t=0,1 ;
\end{array}
$$

and [2] markets clear

$$
\sum_{i=1}^{2} X_{i l}^{t}=\sum_{i=1}^{2} E_{i l}^{t}, \quad t=0,1 ; \quad l=1,2 .
$$

[Definition] General Equilibrium with Across Period Budget Constraints

A general equilibrium for this economy with combined budget constraints over periods is characterized by a price system and consumption of goods by countries $\left(\left(P_{l}^{t}: t=0,1 ; l=\right.\right.$ $\left.1,2),\left(X_{i l}^{t}: t=0,1 ; i=1,2 ; l=1,2\right)\right)$ such that

[1] given $\left(P_{l}^{t} ; t=0,1, l=1,2\right)$, for $\mathrm{i}=1,2,\left(X_{i l}^{t} ; t=0,1, l=1,2\right)$ solves the utility maximization problem subject to the combined across period budget constraint (8),

$$
\begin{array}{ll}
\max & U_{i}=u_{i}^{0}\left(X_{i 1}^{0}, X_{i 2}^{0}\right)+\frac{1}{1+\rho_{i}} u_{i}^{1}\left(X_{i 1}^{1}, X_{i 2}^{1}\right) \\
\text { s.t. } & \sum_{t=0}^{1} \sum_{l=1}^{2} P_{l}^{t}\left(1+T_{i l}^{t}\right) X_{i l}^{t}=\sum_{t=0}^{1} \sum_{l=1}^{2} P_{l}^{t}\left(1+T_{i l}^{t}\right) E_{i l}^{t}+\sum_{t=0}^{1} R_{i}^{t} ;
\end{array}
$$

and [2] markets clear

$$
\sum_{i=1}^{2} X_{i l}^{t}=\sum_{i=1}^{2} E_{i l}^{t}, \quad t=0,1 ; \quad l=1,2 .
$$

The combined across periods budget constraint (8) for each individual can also be written as

$$
\begin{aligned}
& \sum_{l=1}^{2} P_{l}^{0}\left(1+T_{i l}^{0}\right) X_{i l}^{0}+F_{i}=\sum_{l=1}^{2} P_{l}^{0}\left(1+T_{i l}^{0}\right) E_{i l}^{0}+R_{i}^{0} \\
& \sum_{l=1}^{2} P_{l}^{1}\left(1+T_{i l}^{1}\right) X_{i l}^{1}=\sum_{l=1}^{2} P_{l}^{1}\left(1+T_{i l}^{1}\right) E_{i l}^{1}+R_{i}^{1}+F_{i}
\end{aligned}
$$


where $F_{i}$ represents the amount of lending (borrowing) by (from) one individual to (by) the other.

The across period budget constraint equilibrium is the same as an equilibrium characterized by a price system and consumption of goods by countries $\left(\left(P_{l}^{t}: t=0,1 ; l=1,2\right),\left(X_{i l}^{t}\right.\right.$ : $t=0,1 ; i=1,2 ; l=1,2))$ such that

[1] given $\left(P_{l}^{t} ; t=0,1, l=1,2\right)$, for $\mathrm{i}=1,2,\left(X_{i l}^{t} ; t=0,1, l=1,2\right)$ solve the utility maximization problem subject to the budget constraints (9) - (10)

$$
\begin{array}{ll}
\max & U_{i}=u_{i}^{0}\left(X_{i 1}^{0}, X_{i 2}^{0}\right)+\frac{1}{1+\rho_{i}} u_{i}^{1}\left(X_{i 1}^{1}, X_{i 2}^{1}\right) \\
\text { s.t. } & \sum_{l=1}^{2} P_{l}^{0}\left(1+T_{i l}^{0}\right) X_{i l}^{0}+F_{i}=\sum_{l=1}^{2} P_{l}^{0}\left(1+T_{i l}^{0}\right) E_{i l}^{0}+R_{i}^{0} \\
& \sum_{l=1}^{2} P_{l}^{1}\left(1+T_{i l}^{1}\right) X_{i l}^{1}=\sum_{l=1}^{2} P_{l}^{1}\left(1+T_{i l}^{1}\right) E_{i l}^{1}+R_{i}^{1}+F_{i}
\end{array}
$$

and [2] markets clear

$$
\sum_{i=1}^{2} X_{i l}^{t}=\sum_{i=1}^{2} E_{i l}^{t} \quad \text { for } t=0,1 \quad \text { and } l=1,2 \quad \text { and } \quad \sum_{i=1}^{2} F_{i}=0 .
$$

Setting the interest rate (for both lenders and borrowers) in the two countries equal to $r$, the combined budget constraints become

$$
\begin{aligned}
& \sum_{l=1}^{2} P_{l}^{0}\left(1+T_{i l}^{0}\right) X_{i l}^{0}+F_{i}=\sum_{l=1}^{2} P_{l}^{0}\left(1+T_{i l}^{0}\right) E_{i l}^{0}+R_{i}^{0} \\
& \sum_{l=1}^{2} P_{l}^{1}\left(1+T_{i l}^{1}\right) X_{i l}^{1}=\sum_{l=1}^{2} P_{l}^{1}\left(1+T_{i l}^{1}\right) E_{i l}^{1}+R_{i}^{1}+[1+r] F_{i}
\end{aligned}
$$

Thus, the across period equilibrium is equivalent to an equilibrium with the same lending and borrowing interest rate, characterized by a price system and consumption of goods by countries $\left(\left(P_{l}^{t}: t=0,1 ; l=1,2\right),\left(X_{i l}^{t}: t=0,1 ; i=1,2 ; l=1,2\right)\right)$ such that

[1] given $\left(P_{l}^{t} ; t=0,1, l=1,2\right)$, for $\mathrm{i}=1,2,\left(X_{i l}^{t} ; t=0,1, l=1,2\right)$ solve the utility maximization problem subject to the budget constraints (11) - (12)

$$
\begin{array}{ll}
\max & U_{i}=u_{i}^{0}\left(X_{i 1}^{0}, X_{i 2}^{0}\right)+\frac{1}{1+\rho_{i}} u_{i}^{1}\left(X_{i 1}^{1}, X_{i 2}^{1}\right) \\
\text { s.t. } & \sum_{l=1}^{2} P_{l}^{0}\left(1+T_{i l}^{0}\right) X_{i l}^{0}+F_{i}=\sum_{l=1}^{2} P_{l}^{0}\left(1+T_{i l}^{0}\right) E_{i l}^{0}+R_{i}^{0} \\
& \sum_{l=1}^{2} P_{l}^{1}\left(1+T_{i l}^{1}\right) X_{i l}^{1}=\sum_{l=1}^{2} P_{l}^{1}\left(1+T_{i l}^{1}\right) E_{i l}^{1}+R_{i}^{1}+[1+r] F_{i}
\end{array}
$$


and [2] markets clear

$$
\sum_{i=1}^{2} X_{i l}^{t}=\sum_{i=1}^{2} E_{i l}^{t} \quad \text { for } t=0,1 \quad \text { and } l=1,2 \quad \text { and } \quad \sum_{i=1}^{2} F_{i}=0 .
$$

If tariff rates are zero on both products in both countries at both dates $\left(T_{i l}^{t}=0\right.$ for $t=0,1$ and $i=1,2$ and $l=1,2)$, then these equilibria are also free trade competitive equilibria.

Comparing across these equilibria in this simplified world enable us to consider the effects of services liberalization (in the sense assumed here) in the presence of restrictions on goods trade. 


\section{Numerical Analysis of Trade Liberalization in a Simple Joint Spatial Inter-Temporal Trade Model}

We can use the structures presented in the previous section in numerical equilibrium analysis by comparing across equilibria for particular parameterizations and assessing the impacts of alternative trade liberalizations. In using the model structure set out above to compute equilibria for these economies we also need to assume that the direction of trade is predetermined. This may be that country 1 imports good $1\left(X_{11}^{t} \geq E_{11}^{t}\right.$ and $\left.T_{11}^{t} \geq 0\right)$ and exports good $2\left(X_{12}^{t} \leq E_{12}^{t}\right.$ and $\left.T_{12}^{t}=0\right)$, while country 2 exports good $1\left(X_{21}^{t} \leq E_{21}^{t}\right.$ and $\left.T_{21}^{t}=0\right)$ and imports good $2\left(X_{22}^{t} \geq E_{22}^{t}\right.$ and $\left.T_{22}^{t} \geq 0\right)$. In this case the price of good 1 is $P_{11}^{t}=P_{1}^{t}\left(1+T_{11}^{t}\right)$ for buyers in country 1 and $P_{21}^{t}=P_{1}^{t}$ for sellers from country 2 , and the price of good 2 is $P_{12}^{t}=P_{2}^{t}$ for sellers from country 1 and $P_{22}^{t}=P_{2}^{t}\left(1+T_{22}^{t}\right)$ for buyers in country 2 . In this case tariff revenues at date $t$ are given by

$$
R_{1}^{t}=P_{1}^{t} T_{11}^{t}\left(X_{11}^{t}-E_{11}^{t}\right) \quad \text { and } \quad R_{2}^{t}=P_{2}^{t} T_{22}^{t}\left(X_{22}^{t}-E_{22}^{t}\right)
$$

Table 1 sets out a parameterization for a Cobb - Douglas inter-temporal spatial 2 country economy with and without tariffs. The parameter values used here are arbitrarily selected. Except for the share parameters this is a symmetric specification across countries including of the inter-temporal discount factors used in the two countries. Tariff rates are specified as positive when the direction of trade implies an import by that country. We later perform parametric variation around this specification to search for other examples of welfare worsening liberalization of services in the presence of tariffs and also analyze other forms of liberalization.

In Table 2 we report Hicksian Equivalent Variation money metric welfare measures of the impacts of various liberalizations both for individual economies and for the world using the parametric specification in Table 1. In this table Hicksian measures are expressed as a percentage of reference equilibrium (pre-liberalization) incomes. Here, results show that goods liberalization yields a welfare gain, while services liberalization in the presence of tariffs yields a welfare loss. Larger gains occur if tariffs and services are jointly removed, implying these two liberalization have non additive effects. Services liberalization if tariffs are already zero yields gains instead of losses. Goods liberalization when services are already liberalized yields considerably larger gains. 
We then use parametric variation around this base case specification to reevaluate the gains from alternative liberalizations. The left part of Figure 1 shows how welfare measures of the global impact of liberalization in services behave if we vary the value of $\rho_{2}$ (the inter-temporal discount rate in country 2). For low values less than 0.0447 and higher than 0.2116 a gain occurs, indicating the parametric sensitivity of the sign of the welfare impact of services liberalization. In the right panel when the same discount factor in both countries is varied, for all $\rho$ values there is a loss.

As we vary only the value of $\rho_{2}$ in further cases (not shown in Figure 1), the EV as a $\%$ of reference equilibrium incomes is positive for the following four cases: (1) moving from base case to goods liberalization, (2) moving to services liberalization when goods are already liberalized, (3) moving to goods liberalization when services are already liberalized, and (4) moving from base case to joint goods and services liberalization. In the right part of Figure 1 , when we vary the value of $\rho$ for both countries, the $\mathrm{EV}$ as a $\%$ of reference equilibrium incomes in the case of services liberalization remains as negative. For the other three cases: (1) moving from base case to goods liberalization, (2) moving to goods liberalization when services are already liberalized, and (3) moving from base case to joint goods and services liberalization, the country $1 \mathrm{EV}$ impacts change from gain to loss, and country 2 and the world (2 countries) gain.

Tables 3 and 4 show comparable results for the CES case with inter-commodity preference elasticities of substitution set (arbitrarily) to 2.0 and 0.5 for the 2 countries. Here there is a gain rather than a loss under services liberalization, and effects compared to the Cobb - Douglas case are larger. Figure 2 shows how welfare measures of the impacts of services liberalization behave for similar parametric variations for $\rho$ (inter-temporal discount rates). Here, when $\rho_{2}$ is varied only for country 2 in the left part loss occur with low values, and gains for higher values, indicating the parametric sensitivity of the sign of the welfare impact of services liberalization. A sharply different picture change country impacts compared to the Cobb Douglas case emerges for the case where $\rho$ is valued for both countries. 
Table 1 A Parameterization of a Cobb - Douglas Spatial and Inter-Temporal Economy Used to Analyze Joint Goods and Services Liberalization

Inter-Temporal Discount Factor $\quad \rho_{1}=0.10 \quad$ and $\quad \rho_{2}=0.10$

\begin{tabular}{|c|c|c|c|c|}
\hline \multirow{2}{*}{$\begin{array}{c}\text { Share Parameters } \\
\alpha_{i l}^{t}\end{array}$} & \multicolumn{2}{|c|}{ Period 0 } & \multicolumn{2}{c|}{ Period 1 } \\
\cline { 2 - 5 } & Good 1 & Good 2 & Good 1 & Good 2 \\
\hline Country 1 & 0.70 & 0.30 & 0.60 & 0.40 \\
\hline Country 2 & 0.40 & 0.60 & 0.30 & 0.70 \\
\hline
\end{tabular}

\begin{tabular}{|c|c|c|c|c|}
\hline \multirow{2}{*}{$\begin{array}{c}\text { Initial Endowments } \\
E_{i l}^{t}\end{array}$} & \multicolumn{2}{|c|}{ Period 0} & \multicolumn{2}{c|}{ Period 1 } \\
\cline { 2 - 5 } & Good 1 & Good 2 & Good 1 & Good 2 \\
\hline Country 1 & 40 & 80 & 40 & 80 \\
\hline Country 2 & 80 & 40 & 80 & 40 \\
\hline
\end{tabular}

\begin{tabular}{|c|c|c|c|c|}
\hline \multirow{2}{*}{$\begin{array}{c}\text { Initial Tariff Rates } \\
T_{i l}^{t}\end{array}$} & \multicolumn{2}{|c|}{ Period 0} & \multicolumn{2}{c|}{ Period 1 } \\
\cline { 2 - 5 } & Good 1 & Good 2 & Good 1 & Good 2 \\
\hline Country 1 & 0.10 & 0.00 & 0.05 & 0.00 \\
\hline Country 2 & 0.00 & 0.05 & 0.00 & 0.10 \\
\hline
\end{tabular}


Table 2 Welfare Consequences of Alternative Liberalizations

Using the Cobb - Douglas Economy Parameterization from Table 1

\begin{tabular}{|c|c|c|c|}
\hline \multirow{2}{*}{} & \multicolumn{2}{|c|}{$\begin{array}{c}\text { Hicksian Equivalent Variation as \% } \\
\text { of Original Equilibrium Income from }\end{array}$} \\
\cline { 2 - 4 } & Country 1 & Country 2 & $\begin{array}{c}\text { Both Countries } \\
\text { (The World) }\end{array}$ \\
\hline $\begin{array}{c}\text { Moving from Base Case to } \\
\text { Goods Liberalization }\end{array}$ & 0.0373 & 0.0766 & 0.0570 \\
\hline $\begin{array}{c}\text { Moving to Services Liberalization } \\
\text { when Goods Are Already liberalized }\end{array}$ & 0.0069 & 0.0070 & 0.0070 \\
\hline $\begin{array}{c}\text { Moving from Base Case to } \\
\text { Services Liberalization }\end{array}$ & -0.1530 & -0.1535 & -0.1533 \\
\hline $\begin{array}{c}\text { Moving to Goods Liberalization } \\
\text { when Services Are Already Liberalized }\end{array}$ & 0.1975 & 0.2375 & 0.2175 \\
\hline $\begin{array}{c}\text { Moving from Base Case to } \\
\text { Joint Goods and Services Liberalization }\end{array}$ & 0.0442 & 0.0837 & 0.0640 \\
\hline
\end{tabular}


Table 3 A Parameterization of a CES Spatial Inter-Temporal Economy Used to Analyze Joint Goods and Services Liberalization

\begin{tabular}{|c|c|c|}
\hline $\begin{array}{c}\text { Elasticity of Substitution } \\
\sigma_{i}^{t}\end{array}$ & Period 0 & Period 1 \\
\hline Country 1 & 2.00 & 0.50 \\
\hline Country 2 & 0.50 & 2.00 \\
\hline
\end{tabular}

Inter-Temporal Discount Factor $\rho_{1}=0.10 \quad$ and $\quad \rho_{2}=0.10$

\begin{tabular}{|c|c|c|c|c|}
\hline \multirow{2}{*}{$\begin{array}{c}\text { Share Parameters } \\
\alpha_{i l}^{t}\end{array}$} & \multicolumn{2}{|c|}{ Period 0 } & \multicolumn{2}{c|}{ Period 1 } \\
\cline { 2 - 5 } & Good 1 & Good 2 & Good 1 & Good 2 \\
\hline Country 1 & 0.70 & 0.30 & 0.60 & 0.40 \\
\hline Country 2 & 0.40 & 0.60 & 0.30 & 0.70 \\
\hline
\end{tabular}

\begin{tabular}{|c|c|c|c|c|}
\hline \multirow{2}{*}{$\begin{array}{c}\text { Initial Endowments } \\
E_{i l}^{t}\end{array}$} & \multicolumn{2}{|c|}{ Period 0} & \multicolumn{2}{c|}{ Period 1 } \\
\cline { 2 - 5 } & Good 1 & Good 2 & Good 1 & Good 2 \\
\hline Country 1 & 40 & 80 & 40 & 80 \\
\hline Country 2 & 80 & 40 & 80 & 40 \\
\hline
\end{tabular}

\begin{tabular}{|c|c|c|c|c|}
\hline Initial Tariff Rates & \multicolumn{2}{|c|}{ Period 0} & \multicolumn{2}{c|}{ Period 1 } \\
\cline { 2 - 5 }$T_{i l}^{t}$ & Good 1 & Good 2 & Good 1 & Good 2 \\
\hline Country 1 & 0.10 & 0.00 & 0.05 & 0.00 \\
\hline Country 2 & 0.00 & 0.05 & 0.00 & 0.10 \\
\hline
\end{tabular}


Table 4 Welfare Consequences of Alternative Liberalizations

Using the CES Economy Parameterization from Table 3

\begin{tabular}{|c|c|c|c|}
\hline \multirow{2}{*}{} & \multicolumn{2}{|c|}{$\begin{array}{c}\text { Hicksian Equivalent Variation as \% } \\
\text { of Original Equilibrium Income from }\end{array}$} \\
\cline { 2 - 4 } & Country 1 & Country 2 & $\begin{array}{c}\text { Both Countries } \\
\text { (The World) }\end{array}$ \\
\hline $\begin{array}{c}\text { Moving from Base Case to } \\
\text { Goods Liberalization }\end{array}$ & 0.0092 & 0.1605 & 0.0848 \\
\hline $\begin{array}{c}\text { Moving to Services Liberalization } \\
\text { when Goods Are Already liberalized }\end{array}$ & 0.2848 & 0.3947 & 0.3397 \\
\hline $\begin{array}{c}\text { Moving from Base Case to } \\
\text { Services Liberalization }\end{array}$ & 0.1812 & 0.4170 & 0.2991 \\
\hline $\begin{array}{c}\text { Moving to Goods Liberalization } \\
\text { when Services Are Already Liberalized }\end{array}$ & 0.1126 & 0.1383 & 0.1254 \\
\hline $\begin{array}{c}\text { Moving from Base Case to } \\
\text { Joint Goods and Services Liberalization }\end{array}$ & 0.2940 & 0.5558 & 0.4249 \\
\hline
\end{tabular}




\section{A Model of Spatial and Inter-Temporal Trade with Costly Intermediation Services}

The model used in the previous two sections is highly simplified in that it considers a general equilibrium structure with no intermediation in autarky and costless foreign supplied intermediation services under service trade liberalization. Where intermediation occurs under liberalization, the same interest rate for lending and borrowing applies in both countries, which is equivalent to an across period budget constraint equilibrium for the two countries combined. A more realistic structure involves costly intermediation with different costs faced by service providers in the two countries. Under liberalization of service trade more efficient foreign service providers then displace domestic service providers in one of the country markets. To develop such a structure we need a model in which interest rates are different between lenders and borrowers due to intermediation costs, and we also need to use different concepts of equilibrium.

We first consider a case where there is still costless intermediation between periods in each country, but intermediation across countries within the period is allowed up to some level $F_{i}$. The budget constraint for each country $i$ then becomes

$$
\begin{aligned}
& \sum_{l=1}^{2} P_{l}^{0}\left(1+T_{i l}^{0}\right) X_{i l}^{0}+F_{i}=I_{i}^{0} \\
& \sum_{l=1}^{2} P_{l}^{1}\left(1+T_{i l}^{1}\right) X_{i l}^{1}=I_{i}^{1}+\left[1+r_{i}\right] F_{i}
\end{aligned}
$$

which implies

$$
\begin{aligned}
& \sum_{l=1}^{2} P_{l}^{0}\left(1+T_{i l}^{0}\right) X_{i l}^{0}+F_{i}=\sum_{l=1}^{2} P_{l}^{0}\left(1+T_{i l}^{0}\right) E_{i l}^{0}+R_{i}^{0} \\
& \sum_{l=1}^{2} P_{l}^{1}\left(1+T_{i l}^{1}\right) X_{i l}^{1}=\sum_{l=1}^{2} P_{l}^{1}\left(1+T_{i l}^{1}\right) E_{i l}^{1}+R_{i}^{1}+\left[1+r_{i}\right] F_{i}
\end{aligned}
$$

where $F_{i}$ is the amount borrowed by a consumer in one country from the other country consumer via banks. With costless intermediation, $r_{i}$ is the lending and borrowing interest rate in country $i$. In this structure, $F_{i}$ can be set by policy (allowable credit, or money issuance) with $r_{i}$ endogenously determined, or $r_{i}$ can be set with $F_{i}$ endogenously determined.

In the costless intermediation case, a general equilibrium for this economy (with the interest rate for lending and borrowing $r_{i}$ for $\left.i=1,2\right)$ is characterized by a price system and 
consumption of goods by countries $\left(\left(P_{l}^{t}: t=0,1 ; l=1,2\right),\left(X_{i l}^{t}: t=0,1 ; i=1,2 ; l=1,2\right)\right)$ such that

[1] given $\left(P_{l}^{t} ; t=0,1, l=1,2\right)$, for $\mathrm{i}=1,2,\left(X_{i l}^{t} ; t=0,1, l=1,2\right)$ solve the utility maximization problem subject to the budget constraints (14) - (15)

$$
\begin{array}{ll}
\max & U_{i}=u_{i}^{0}\left(X_{i 1}^{0}, X_{i 2}^{0}\right)+\frac{1}{1+\rho_{i}} u_{i}^{1}\left(X_{i 1}^{1}, X_{i 2}^{1}\right) \\
\text { s.t. } & \sum_{l=1}^{2} P_{l}^{0}\left(1+T_{i l}^{0}\right) X_{i l}^{0}+F_{i}=\sum_{l=1}^{2} P_{l}^{0}\left(1+T_{i l}^{0}\right) E_{i l}^{0}+R_{i}^{0} \\
& \sum_{l=1}^{2} P_{l}^{1}\left(1+T_{i l}^{1}\right) X_{i l}^{1}=\sum_{l=1}^{2} P_{l}^{1}\left(1+T_{i l}^{1}\right) E_{i l}^{1}+R_{i}^{1}+\left[1+r_{i}\right] F_{i}
\end{array}
$$

and [2] markets clear

$$
\begin{gathered}
\sum_{i=1}^{2} X_{i l}^{0}=\sum_{i=1}^{2} E_{i l}^{0} \text { and } \sum_{i=1}^{2} X_{i l}^{1} \leq \sum_{i=1}^{2} E_{i l}^{1} \text { for } l=1,2 \\
\sum_{i=1}^{2} F_{i}=0
\end{gathered}
$$

If we then consider costly intermediation services with (in the no services trade case) different interest rates for lending and borrowing for each country, the budget constraints for each country $i$ are

$$
\begin{aligned}
& \sum_{l=1}^{2} P_{l}^{0}\left(1+T_{i l}^{0}\right) X_{i l}^{0}+F_{i}=I_{i}^{0} \\
& \sum_{l=1}^{2} P_{l}^{1}\left(1+T_{i l}^{1}\right) X_{i l}^{1}=I_{i}^{1}+\left[1+r_{i}\left(F_{i}\right)\right] F_{i}
\end{aligned}
$$

which imply

$$
\begin{aligned}
& \sum_{l=1}^{2} P_{l}^{0}\left(1+T_{i l}^{0}\right) X_{i l}^{0}+F_{i}=\sum_{l=1}^{2} P_{l}^{0}\left(1+T_{i l}^{0}\right) E_{i l}^{0}+R_{i}^{0} \\
& \sum_{l=1}^{2} P_{l}^{1}\left(1+T_{i l}^{1}\right) X_{i l}^{1}=\sum_{l=1}^{2} P_{l}^{1}\left(1+T_{i l}^{1}\right) E_{i l}^{1}+R_{i}^{1}+\left[1+r_{i}\left(F_{i}\right)\right] F_{i}
\end{aligned}
$$

We can represent deposit and borrowing rates as

$$
r_{i}\left(F_{i}\right)= \begin{cases}r_{i}^{D}, & \text { if } F_{i} \geq 0 \\ r_{i}^{B}, & \text { if } F_{i} \leq 0\end{cases}
$$


where $r_{i}^{D}$ and $r_{i}^{B}$ are the interest rates for lending (deposits or saving) and borrowing in country $i$, and $\left[1+r_{i}\left(F_{i}\right)\right] F_{i}=\left[1+r_{i}^{D}\right] F_{i}^{+}-\left[1+r_{i}^{B}\right] F_{i}^{-}$. The budget constraints (18) - (19) can then be written as

$$
\begin{aligned}
& \sum_{l=1}^{2} P_{l}^{0}\left(1+T_{i l}^{0}\right) X_{i l}^{0}+F_{i}=\sum_{l=1}^{2} P_{l}^{0}\left(1+T_{i l}^{0}\right) E_{i l}^{0}+R_{i}^{0} \\
& \sum_{l=1}^{2} P_{l}^{1}\left(1+T_{i l}^{1}\right) X_{i l}^{1}=\sum_{l=1}^{2} P_{l}^{1}\left(1+T_{i l}^{1}\right) E_{i l}^{1}+R_{i}^{1}+\left[1+r_{i}^{D}\right] F_{i}^{+}-\left[1+r_{i}^{B}\right] F_{i}^{-}
\end{aligned}
$$

Since in the presence of costly intermediation, $r_{i}^{B} \geq r_{i}^{D}$ for $i=1,2$, we can represent intermediation costs in country $i$ by the parameter $\lambda_{i}$ such that $r_{i}^{B}=\left(1+\lambda_{i}\right) r_{i}^{D}$. If intermediation services are provided by banks in country $i, \lambda_{1}>\lambda_{2}$ implies that banks in country 2 are more efficient than in country 1 ; while $\lambda_{2}>\lambda_{1}$ implies that banks in country 1 are more efficient than in country 2 .

This then allow us to characterize two equilibria in the presence of costly banking services; one with no trade in banking services (autarky in banking) and one with free trade in banking services.

\section{Equilibrium with Autarky in Intermediation Services (Intermediation Ser-} vices Are Only Provided by Domestic Banks)

If we assume that depositors can deposit money in any bank, they receive the same interest rate in both countries, i.e. $r^{D}=r_{1}^{D}=r_{2}^{D}$. But if borrowers can only borrow from domestic banks, $r_{1}^{B} \neq r_{2}^{B}$. In autarky, intermediation services are only provided by domestic banks and the intermediation costs are $I C_{i}=r_{i}^{B}-r^{D}=\lambda_{i} r^{D}$. If $I C_{1}>I C_{2}$, then banking services cost more in country 1 ; if $I C_{2}>I C_{1}$, then banking services cost more in country 2. The value (cost) of intermediation services is given by $\left(r_{i}^{B}-r^{D}\right) F_{i}=\lambda_{i} r^{D} F_{i}$ for $i=1,2$.

A general equilibrium for an international economy with autarky in intermediation services and different interest rates for lending and borrowing (related through $\lambda_{i}$ for $i=1,2$ ) is characterized by a price system and consumption of goods by countries $\left(r^{D},\left(P_{l}^{t}: t=\right.\right.$ $\left.0,1 ; l=1,2),\left(X_{i l}^{t}: t=0,1 ; i=1,2 ; l=1,2\right)\right)$ such that

[1] given $r^{D}$ and $\left.\left(P_{l}^{t} ; t=0,1, l=1,2\right)\right)$, for $\mathrm{i}=1,2,\left(X_{i l}^{t} ; t=0,1, l=1,2\right)$ solve the 
utility maximization problem subject to the budget constraints (18) - (19)

$$
\begin{array}{ll}
\max & U_{i}=u_{i}^{0}\left(X_{i 1}^{0}, X_{i 2}^{0}\right)+\frac{1}{1+\rho_{i}} u_{i}^{1}\left(X_{i 1}^{1}, X_{i 2}^{1}\right) \\
\text { s.t. } & \sum_{l=1}^{2} P_{l}^{0}\left(1+T_{i l}^{0}\right) X_{i l}^{0}+F_{i}=\sum_{l=1}^{2} P_{l}^{0}\left(1+T_{i l}^{0}\right) E_{i l}^{0}+R_{i}^{0} \\
& \sum_{l=1}^{2} P_{l}^{1}\left(1+T_{i l}^{1}\right) X_{i l}^{1}=\sum_{l=1}^{2} P_{l}^{1}\left(1+T_{i l}^{1}\right) E_{i l}^{1}+R_{i}^{1}+\left[1+r_{i}\left(F_{i}\right)\right] F_{i}
\end{array}
$$

and [2] markets clear

$$
\sum_{i=1}^{2} X_{i l}^{0}=\sum_{i=1}^{2} E_{i l}^{0} \text { and } \sum_{i=1}^{2} X_{i l}^{1} \leq \sum_{i=1}^{2} E_{i l}^{1} \quad \text { for } \quad l=1,2
$$

If we then allow trade to occur in intermediation services, this yields a different equilibrium concept to that used earlier in the costless intermediation case.

Equilibrium with Free Trade in Intermediation Services (Intermediation Services Are Provided by Either Domestic or Foreign Banks)

If depositors receive the same interest rate anywhere, once again $r^{D}=r_{1}^{D}=r_{2}^{D}$, since individuals can deposit money in any bank. But with free trade in banking services, borrowers can borrow from either domestic or foreign banks, which implies that the same borrowing rate applies anywhere, i.e. $r^{B}=\min \left\{r_{1}^{B}, r_{2}^{B}\right\}=[1+\lambda] r^{D}$, where $\lambda=\min \left\{\lambda_{1}, \lambda_{2}\right\}$. Intermediation services in this case can be provided by either domestic or foreign banks. Intermediation costs are $I C=r^{B}-r^{D}=\lambda r^{D}$ across the two countries, which means that the more efficient country suppliers provide intermediation services to both of the two countries. The value (cost) of intermediation services are $\left(r^{B}-r^{D}\right) F_{i}=\lambda r^{D} F_{i}$ for $i=1,2$.

A general equilibrium for this economy with different interest rates for lending and borrowing (related through $\lambda_{i}$ for $i=1,2$ ) is characterized by a price system and consumption of goods by countries $\left(r^{D},\left(P_{l}^{t}: t=0,1 ; l=1,2\right),\left(X_{i l}^{t}: t=0,1 ; i=1,2 ; l=1,2\right)\right)$ such that

[1] given $r^{D}$ and $\left(P_{l}^{t} ; t=0,1, l=1,2\right)$, for $\mathrm{i}=1,2,\left(X_{i l}^{t} ; t=0,1, l=1,2\right)$ solve the utility maximization problem subject to the budget constraints (18) - (19)

$$
\begin{array}{ll}
\max & U_{i}=u_{i}^{0}\left(X_{i 1}^{0}, X_{i 2}^{0}\right)+\frac{1}{1+\rho_{i}} u_{i}^{1}\left(X_{i 1}^{1}, X_{i 2}^{1}\right) \\
\text { s.t. } & \sum_{l=1}^{2} P_{l}^{0}\left(1+T_{i l}^{0}\right) X_{i l}^{0}+F_{i}=\sum_{l=1}^{2} P_{l}^{0}\left(1+T_{i l}^{0}\right) E_{i l}^{0}+R_{i}^{0} \\
& \sum_{l=1}^{2} P_{l}^{1}\left(1+T_{i l}^{1}\right) X_{i l}^{1}=\sum_{l=1}^{2} P_{l}^{1}\left(1+T_{i l}^{1}\right) E_{i l}^{1}+R_{i}^{1}+\left[1+r\left(F_{i}\right)\right] F_{i}
\end{array}
$$


and [2] markets clear

$$
\sum_{i=1}^{2} X_{i l}^{0}=\sum_{i=1}^{2} E_{i l}^{0} \quad \text { and } \quad \sum_{i=1}^{2} X_{i l}^{1} \leq \sum_{i=1}^{2} E_{i l}^{1} \quad \text { for } \quad l=1,2
$$

where

$$
r_{i}\left(F_{i}\right)= \begin{cases}r^{D}, & \text { if } F_{i} \geq 0 \\ r^{B}, & \text { if } F_{i} \leq 0\end{cases}
$$

Table 5 sets out a parameterization for a Cobb - Douglas economy with tariffs for this model. The parameters of inter-temporal discount factors, share parameters, initial endowment, and initial tariff rates are taken from Table 1 in Section 3. The intermediation cost factors are assumed to be $\lambda_{1}=0.25$ and $\lambda_{2}=0.50$. We somewhat arbitrarily take $F_{1}=32$ and $F_{2}=-32$ for the base case in which different interest rates prevail in each country. The value of interest rates are $r^{D}=r_{1}^{D}=r_{2}^{D}=0.03995, r_{1}^{B}=0.04994$ and $r_{2}^{B}=0.05993$ in the equilibrium with autarky in intermediation services, and $r^{D}=$ $r_{1}^{D}=r_{2}^{D}=0.08032, r_{1}^{B}=0.10040$ and $r_{2}^{B}=0.12049$ in the equilibrium with free trade in intermediation services.

In Table 6 we report Hicksian Equivalent Variation money metric welfare measures of the impacts of goods and services liberalization both for individual countries and the world for this model. Hicksian measures are expressed as a percentage of reference equilibrium (pre-liberalization) incomes. Here, for computational reasons we consider incomplete goods liberalization in this table which changes tariff rates from $T_{11}^{0}=T_{22}^{1}=0.10$ and $T_{22}^{0}=T_{11}^{1}=$ 0.05 to $T_{11}^{0}=T_{22}^{1}=0.05$ and $T_{22}^{0}=T_{11}^{1}=0.00$. Moving to goods liberalization whether services are or not liberalized yields a welfare gain, while moving to services liberalization whether goods are liberalized or not yields a welfare loss.

We then once again conduct parametric variation around this base case specification and reevaluate the gains from alternative liberalizations. Figure 3 shows how welfare measures of the global impact of liberalization in goods or services behave if we only vary the value of $\rho_{2}$ (the inter-temporal discount rate in country 2). There are losses for country 1 and the world, however, welfare effects change from a loss to a gain for country 2 .

Tables 7 and 8 show comparable results for a CES case with inter-commodity elasticities of substitution set equal to 2.0 and 0.5 in the 2 countries. These yield different results from Table 8 for the Cobb - Douglas case. In Table 8, moving from base case to services liberalization yields a welfare loss. Figure 4 shows how welfare measures of the global impact of liberalization in services behave for similar parametric variations from $\rho_{2}$ (inter-temporal 
discount rate in country 2). In the left part, when $\rho_{2}$ is varied only for country 1 loss occur, country 2 and the world loss with low values, and gains for higher values for the services liberalization whether goods are or not already liberalized. 
Table 5 A Parameterization of a Cobb - Douglas Spatial and Inter-Temporal Economy with Costly Intermediation

Used to Analyze Joint Goods and Services Trade Liberalization

Inter-Temporal Discount Factor $\rho_{1}=0.10 \quad$ and $\quad \rho_{2}=0.10$

\begin{tabular}{|c|c|c|c|c|}
\hline \multirow{2}{*}{$\begin{array}{c}\text { Share Parameters } \\
\alpha_{i l}^{t}\end{array}$} & \multicolumn{2}{|c|}{ Period 0} & \multicolumn{2}{c|}{ Period 1 } \\
\cline { 2 - 5 } & Good 1 & Good 2 & Good 1 & Good 2 \\
\hline Country 1 & 0.70 & 0.30 & 0.60 & 0.40 \\
\hline Country 2 & 0.40 & 0.60 & 0.30 & 0.70 \\
\hline
\end{tabular}

\begin{tabular}{|c|c|c|c|c|}
\hline \multirow{2}{*}{$\begin{array}{c}\text { Initial Endowments } \\
E_{i l}^{t}\end{array}$} & \multicolumn{2}{|c|}{ Period 0 } & \multicolumn{2}{c|}{ Period 1 } \\
\cline { 2 - 5 } & Good 1 & Good 2 & Good 1 & Good 2 \\
\hline Country 1 & 40 & 80 & 40 & 80 \\
\hline Country 2 & 80 & 40 & 80 & 40 \\
\hline
\end{tabular}

\begin{tabular}{|c|c|c|c|c|}
\hline Initial Tariff Rates & \multicolumn{2}{|c|}{ Period 0} & \multicolumn{2}{c|}{ Period 1 } \\
\cline { 2 - 5 }$T_{i l}^{t}$ & Good 1 & Good 2 & Good 1 & Good 2 \\
\hline Country 1 & 0.10 & 0.00 & 0.05 & 0.00 \\
\hline Country 2 & 0.00 & 0.05 & 0.00 & 0.10 \\
\hline
\end{tabular}

Amount Borrowed / Lent $F_{1}=32$ and $\quad F_{2}=-32$

Intermediation Cost Factor $\quad \lambda_{1}=0.25 \quad$ and $\quad \lambda_{2}=0.50$


Table 6 Welfare Consequences of Alternative Liberalizations ${ }^{1}$

Using the Cobb - Douglas Economy Parameterization from Table 1, but with Costly Intermediation

\begin{tabular}{|c|c|c|c|}
\hline \multirow{2}{*}{} & \multicolumn{2}{|c|}{$\begin{array}{c}\text { Hicksian Equivalent Variation as \% } \\
\text { of Original Equilibrium Income from }\end{array}$} \\
\cline { 2 - 4 } & Country 1 & Country 2 & $\begin{array}{c}\text { Both Countries } \\
\text { (The World) }\end{array}$ \\
\hline $\begin{array}{c}\text { Moving from Base Case to } \\
\text { Goods Liberalization }\end{array}$ & 0.0933 & 0.0792 & 0.0863 \\
\hline $\begin{array}{c}\text { Moving to Services Liberalization } \\
\text { when Goods Are Already liberalized }\end{array}$ & -0.0003 & -0.0003 & -0.0003 \\
\hline $\begin{array}{c}\text { Moving from Base Case to } \\
\text { Services Liberalization }\end{array}$ & -0.0015 & -0.0014 & -0.0014 \\
\hline $\begin{array}{c}\text { Moving to Goods Liberalization } \\
\text { when Services Are Already Liberalized }\end{array}$ & 0.0945 & 0.0803 & 0.0874 \\
\hline Moving from Base Case to & & & \\
\hline Joint Goods and Services Liberalization & 0.0931 & 0.0789 & 0.0860 \\
\hline
\end{tabular}

1. The goods liberalization here involves tariff rates which only change from $T_{11}^{0}=T_{22}^{1}=$ 0.10 and $T_{22}^{0}=T_{11}^{1}=0.05$ to $T_{11}^{0}=T_{22}^{1}=0.05$ and $T_{22}^{0}=T_{11}^{1}=0.00$, for case of numerical solution of the model. 
Table 7 A Parameterization of a CES Spatial Inter-Temporal Economy Used to Analyze Joint Goods and Services Liberalization

\begin{tabular}{|c|c|c|}
\hline $\begin{array}{c}\text { Constant Elasticity of Substitution } \\
\sigma_{i}^{t}\end{array}$ & Period 0 & Period 1 \\
\hline Country 1 & 2.00 & 0.50 \\
\hline Country 2 & 0.50 & 2.00 \\
\hline
\end{tabular}

Inter-Temporal Discount Factor $\rho_{1}=0.10 \quad$ and $\quad \rho_{2}=0.10$

\begin{tabular}{|c|c|c|c|c|}
\hline \multirow{2}{*}{$\begin{array}{c}\text { Share Parameters } \\
\alpha_{i l}^{t}\end{array}$} & \multicolumn{2}{|c|}{ Period 0 } & \multicolumn{2}{c|}{ Period 1 } \\
\cline { 2 - 5 } & Good 1 & Good 2 & Good 1 & Good 2 \\
\hline Country 1 & 0.70 & 0.30 & 0.60 & 0.40 \\
\hline Country 2 & 0.40 & 0.60 & 0.30 & 0.70 \\
\hline
\end{tabular}

\begin{tabular}{|c|c|c|c|c|}
\hline \multirow{2}{*}{$\begin{array}{c}\text { Initial Endowments } \\
E_{i l}^{t}\end{array}$} & \multicolumn{2}{|c|}{ Period 0} & \multicolumn{2}{c|}{ Period 1 } \\
\cline { 2 - 5 } & Good 1 & Good 2 & Good 1 & Good 2 \\
\hline Country 1 & 40 & 80 & 40 & 80 \\
\hline Country 2 & 80 & 40 & 80 & 40 \\
\hline
\end{tabular}

\begin{tabular}{|c|c|c|c|c|}
\hline Initial Tariff Rates & \multicolumn{2}{|c|}{ Period 0} & \multicolumn{2}{c|}{ Period 1 } \\
\cline { 2 - 5 }$T_{i l}^{t}$ & Good 1 & Good 2 & Good 1 & Good 2 \\
\hline Country 1 & 0.10 & 0.00 & 0.05 & 0.00 \\
\hline Country 2 & 0.00 & 0.05 & 0.00 & 0.10 \\
\hline
\end{tabular}

Amount Borrowed / Lent $\quad F_{1}=32 \quad$ and $\quad F_{2}=-32$

Intermediation Cost Factor $\quad \lambda_{1}=0.25 \quad$ and $\quad \lambda_{2}=0.50$ 
Table 8 Welfare Consequences of Alternative Liberalizations

Using the CES Economy Parameterization from Table 3, but with Costly Intermediation

\begin{tabular}{|c|c|c|c|}
\hline \multirow{2}{*}{} & \multicolumn{3}{|c|}{$\begin{array}{c}\text { Hicksian Equivalent Variation as \% } \\
\text { of Original Equilibrium Income from }\end{array}$} \\
\cline { 2 - 4 } & Country 1 & Country 2 & $\begin{array}{c}\text { Both Countries } \\
\text { (The World) }\end{array}$ \\
\hline $\begin{array}{c}\text { Moving from Base Case to } \\
\text { Goods Liberalization }\end{array}$ & 12.9822 & 27.9915 & 20.4874 \\
\hline $\begin{array}{c}\text { Moving to Services Liberalization } \\
\text { when Goods Are Already liberalized }\end{array}$ & 0.2970 & 0.6536 & 0.4755 \\
\hline $\begin{array}{c}\text { Moving from Base Case to } \\
\text { Services Liberalization }\end{array}$ & -1.6964 & -0.3275 & -1.0119 \\
\hline $\begin{array}{c}\text { Moving to Goods Liberalization } \\
\text { when Services Are Already Liberalized }\end{array}$ & 14.9785 & 28.9754 & 21.9778 \\
\hline $\begin{array}{c}\text { Moving from Base Case to } \\
\text { Joint Goods and Services Liberalization }\end{array}$ & 13.2796 & 28.6470 & 20.9638 \\
\hline
\end{tabular}




\section{Concluding Remarks and Possible Implications for The World Trading System}

This paper discusses joint liberalization of spatial and inter-temporal trade in a multigood multi-period numerical model. The background to this discussion is the issue of whether services trade liberalization in the WTO under the GATS need necessarily be globally welfare improving if free trade in goods does not already apply, noting that there is little trade literature on multi-period / multi-good models in part because general results are not easily obtained. Here we use a numerical simulation approach which we apply to two models which differ in their complexity.

In a model with costless banking we consider services liberalization to imply foreign banking entry where in autaky no domestic banks exist. Their entry relaxes period by period budget constraints. A more complex model considers domestic and foreign service providers with different (but constant) costs. Liberalization in banking service trade allows domestic residents full access to foreign banks. We consider cases with both Cobb - Douglas and CES preferences over goods within the period, and draw on formalization on asset and spot market equilibrium literature originating with Arrow. We are relatively easily able to produce examples where in the presence of tariffs banking liberalization can be welfare worsening.

How this discussion relates to actual GATS liberalization remains an unresolved issue. The results reported on in earlier sections do not directly bear on actual trade patterns in goods and services in the global economy, nor do they relate to actual barriers in place today. Estimates of international trade in services are notoriously imprecise (see the discussion of measurement of trade in banking services in St.Hilaire and Whalley (1995)), but a commonly used figure (sometimes attributed to WTO Annuals Reports) is that services account for perhaps $\frac{1}{3}$ of combined trade in goods and services. They are also supposedly growing at twice the rate of trade in goods. Tariffs on goods post Uruguay Round are low on most goods (with a few peaks in areas such as textiles), with other restrictions applying through anti dumping duties, quotas (textiles) standards, and other non tariff measures. Services are gradually thought to be heavily restricted through domestic regulation, licensing requirements, conduct and performance restrictions for foreign entities, and related devices.

Under this view of the world, then, depending on cost differentials across domestic and 
foreign services providers is that there could well be net benefits from significant liberalization in services independently of further tariff liberalization. The claim would that there have been be 50 years of tariff liberalization in the GATT / WTO, but with less or little services liberalization. If so, GATS services liberalization could well yield positive gains, but whether this is so needs to be established rather than simply asserted. 


\section{References}

[1] Abrego, L. and J.Whalley (2003) Decomposing Wage Inequality Change Using General Equilibrium Models. Forthcoming in T.J.Kehoe, T.N.Srinivasan, and J.Whalley ed. New Frontier in Equilibrium Modelling, Cambridge University Press.

[2] Chen, Z. and L.Schembri (2002) Measuring the Barriers to Trade in Services: Literature and Methodologies. in J.M.Curtis and D.C.Ciuriak ed. Trade Policy Research, Development of Foreign Affairs and International Trade, Canada 2002.

[3] Chia, N.C. and J.Whalley (1997) A Numerical Example Showing Globally Welfare Worsening Liberalization of International Trade in Banking Services. Journal of Policy Modeling, 19, 119-127.

[4] Dee, P. and K.Hanslow (2000) Multilateral Liberalization of Services Trade. Productivity Commission Staff Research Paper, Ausinfo, Canberra.

[5] Duffie, D. and W.Shafer (1985) Equilibrium in Incomplete Markets: I - A Basic Model of Generic Existence. Journal of Mathematical Economics, 14, 285-300.

[6] Foley, D.K. (1970) Equilibrium with Costly Marketing. Journal of Economic Theory, 2, 276-291.

[7] Francois, J. and L.Schuknecht (2000) International Trade in Financial Services, Competition and Growth Performance. Centre for International Economic Studies, No. 6.

[8] Geanakoplos, J.D. (1990) An Introduction to General Equilibrium with Incomplete Asset Markets. Journal of Mathematical Economics, 19, 1-38.

[9] Harberger, A.C. (1964) Taxation, Resource Allocation and Welfare. in The Role of Direct and Indirect Taxes in the Federal Revenue System, a conference report of the National Bureau of Economic Research and Brookings Institution (Princeton University Press for National Bureau of Economic Research and Brookings Institution, 1964), $25-80$.

[10] Hart, O.D. (1975) On the Optimality of Equilibrium when the Market Structure is Incomplete. Journal of Economic Theory, 11, 418-43. 
[11] Hatta, T. (1977) A Theory of Piecemeal Policy Recommendations. Review of Economic Studies, 44, 1-21.

[12] Hindley, B. and A.Smith (1984) Comparative Advantage and Trade in Services. The World Economy, 7, 368-389.

[13] Hoekman, B. (1995) Assessing the General Agreement on Trade in Services. in W.Martin and L.A.Winters ed. The Uruguay Round and the Developing Economies, Discussion Paper No. 307, World Bank, Washington DC, 327-364.

[14] Kalirajan, K., G.McHuire, D.Nguyen-Hong and M.Schuele (2001) The Price Impact of Restrictions on Banking Services. in C.Findlay and T.Warren ed. Impediments to trade in Services: Measurement and Policy Implications, New York: Routledge.

[15] Magill, M. and M. Quinzii (1996) Theory of incomplete markets. Publisher Cambridge, Massachusetts, MIT Press.

[16] Magill, M. and W. Shafer (1991) Incomplete Markets. in W. Hildenbrand and H. Sonnenschein eds. Handbook of Mathematical Economics. Volume 4. Elsevier Science, New York, 1523-1614

[17] Mattoo, A. (1999) Financial Services and the WTO: Liberalization Commitments of the Developing and Transition Economies. Policy Research Working Paper No. 2184, Developing Research Group, World Bank, Washington DC, 1999.

[18] McCulloch, R. (1990) Services and Uruguay Round. The World Economy, 13, 329340.

[19] Radner, R. (1972) Existence of Equilibrium of Plans, Prices and Price Expectations in a Sequence of Markets, Econometrica, 40, 289-303.

[20] Ryan,C. (1990) Trade Liberalization and Financial Services, The World Economy, 13, 349-366.

[21] St-Hilaire, F. and J.Whalley (1995) Some Estimates of Trade Flows in Banking Services. Review of Income and Wealth, 41, 471-479. 
[22] Werner, J. (1985) Equilibrium in Economies with Incomplete Financial Markets. Journal of Economic Theory, 36, 110-119.

[23] Whalley, J. (2003) Assessing the Benefits to Developing Countries of Liberalization in Services Trade. NBER Working Paper 10181. 
Figure 1 Sensitivity of Welfare Measures of Services Liberalization in Simple Cobb - Douglas Model to Inter-Temporal Discount Factors ( $\rho$ )

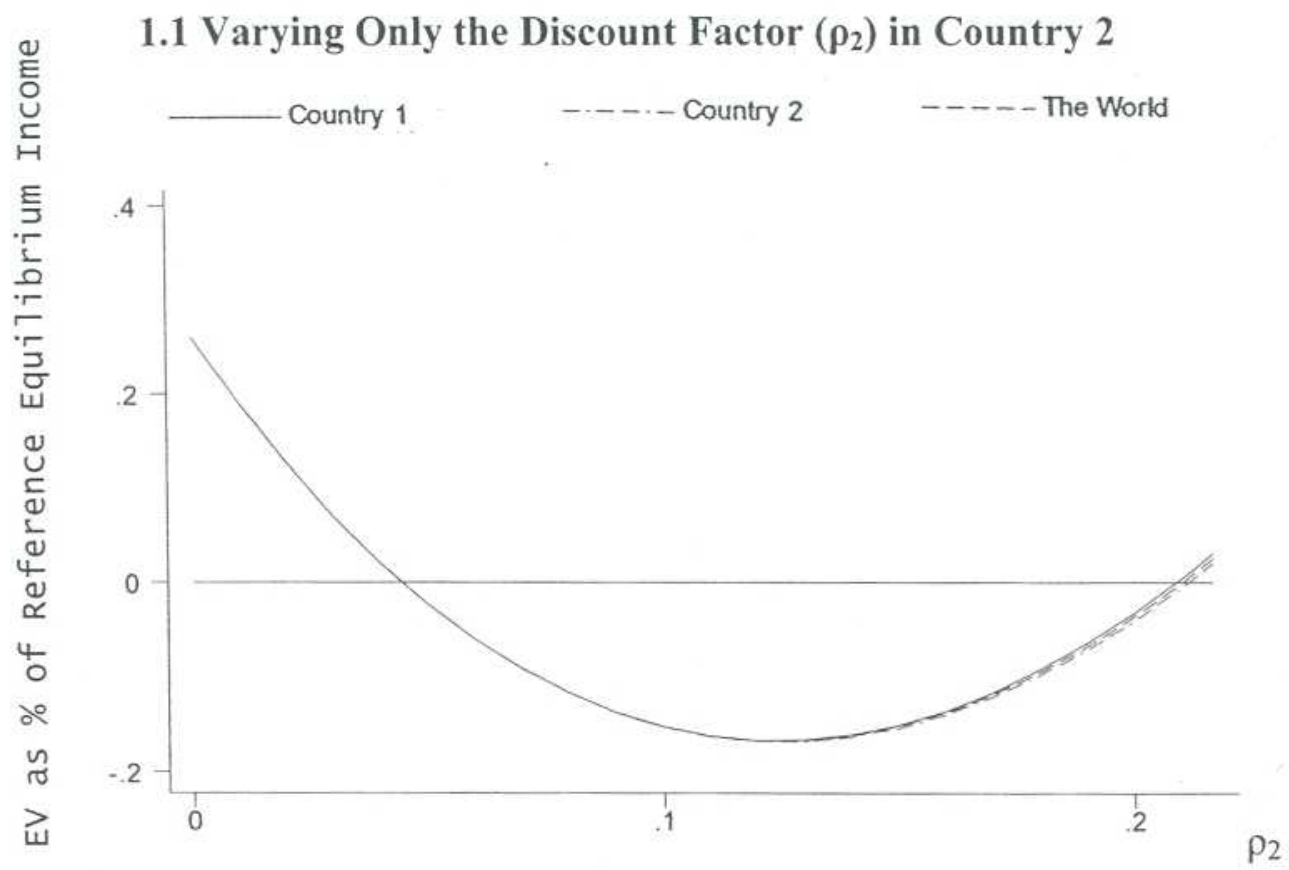

1.2 Varying the Discount Factor $\left(\rho_{1}=\rho_{2}\right)$ in Both Countries

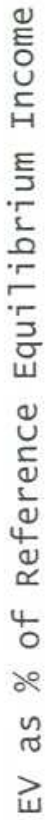

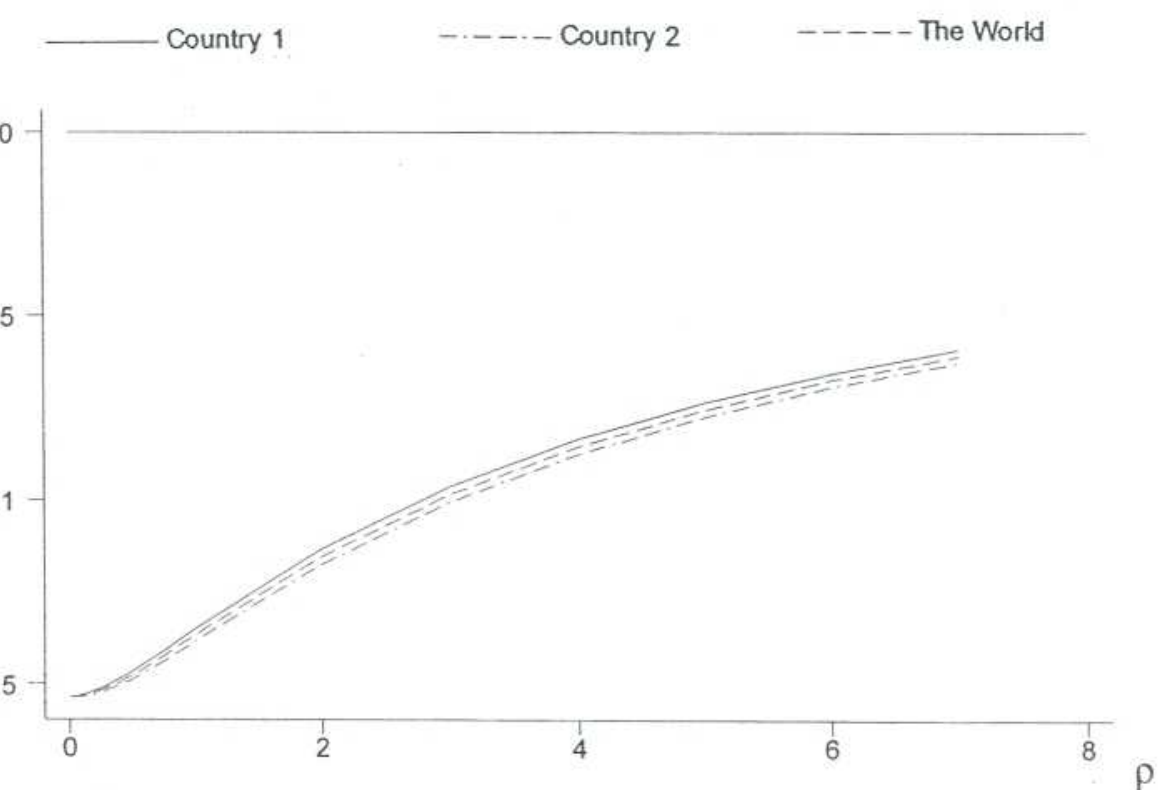


Figure 2 Sensitivity of Welfare Measures of Services Liberalization in Simple CES Model to Inter-Temporal Discount Factors $(\rho)$

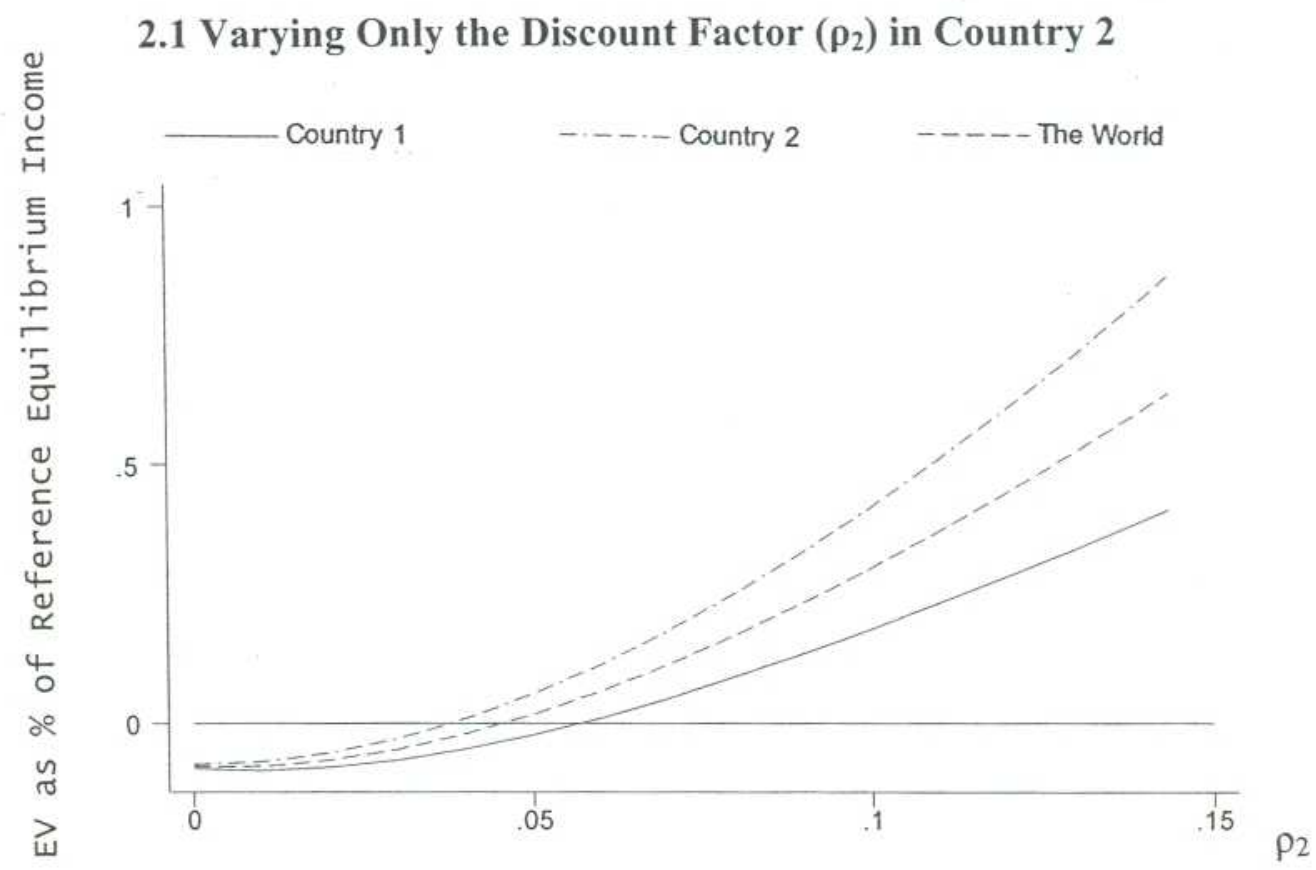

2.2 Varying the Discount Factor $\left(\rho_{1}=\rho_{2}\right)$ in Both Countries

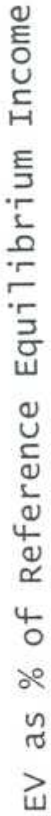
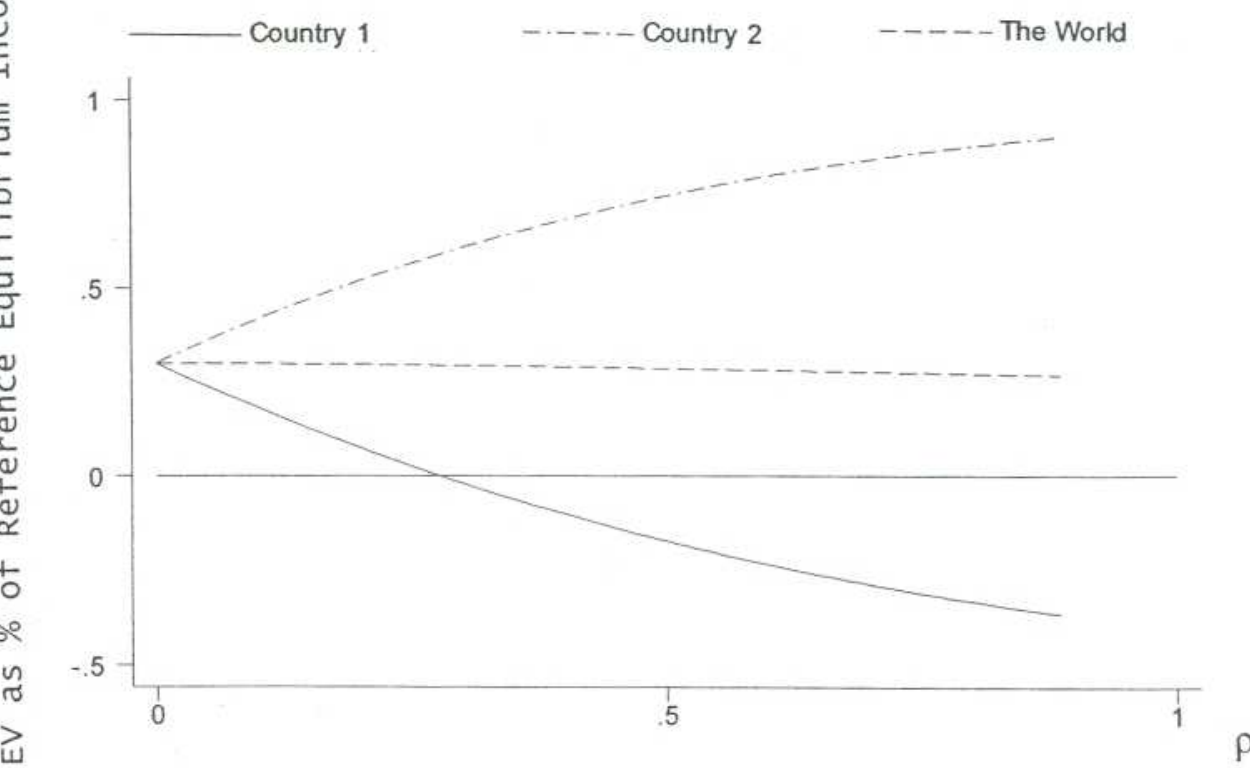
Figure 3 Sensitivity of Welfare Measures of Services Liberalization in Simple Cobb - Douglas Model to Inter-Temporal Discount Factors ( $\rho$ )

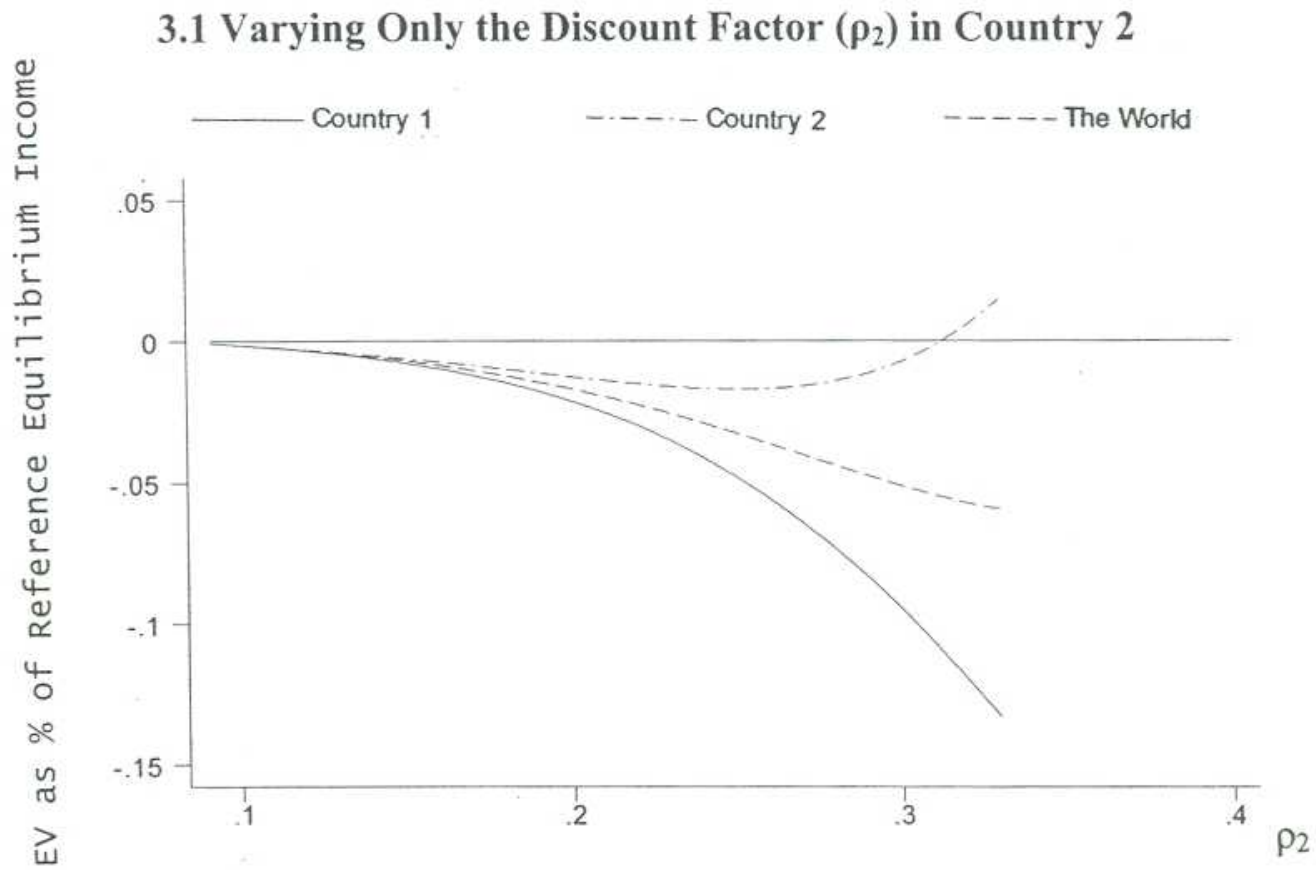

3.2 Varying the Discount Factor $\left(\rho_{1}=\rho_{2}\right)$ in Both Countries

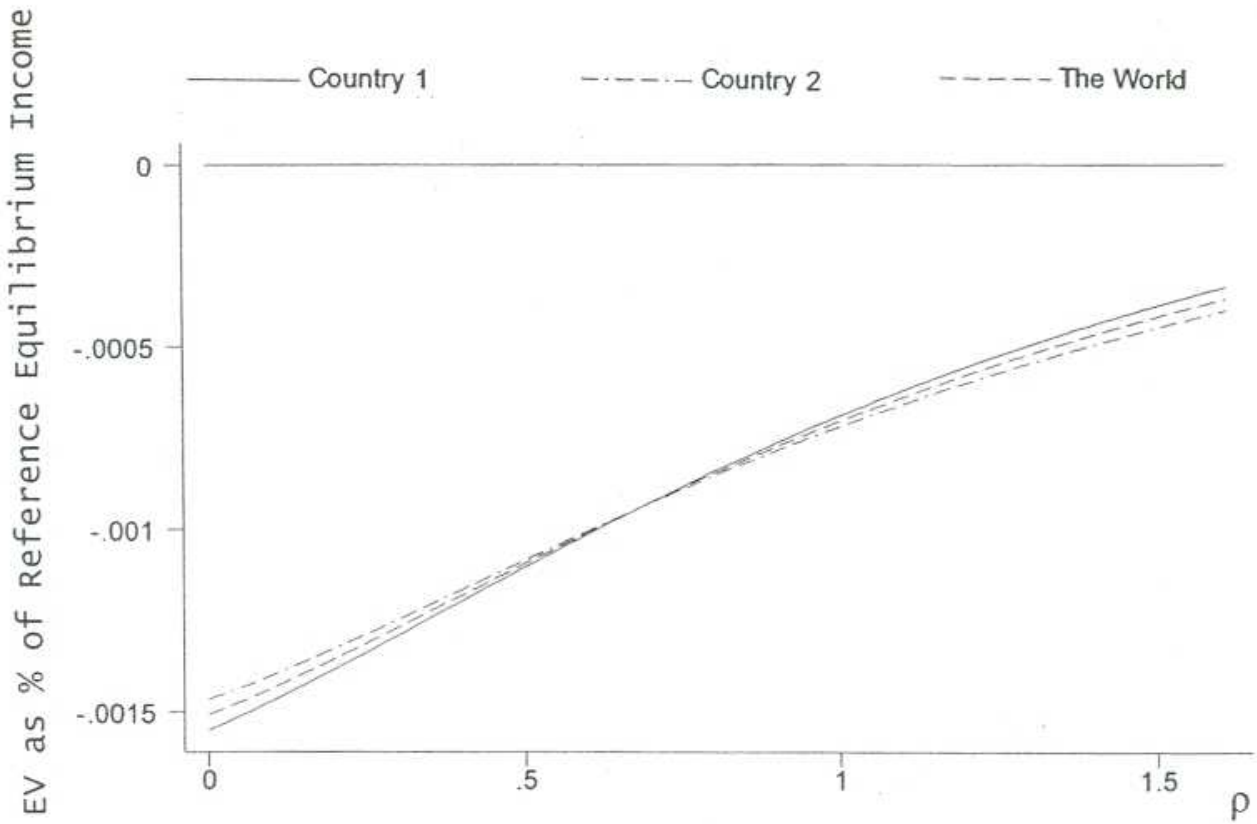


Figure 4 Sensitivity of Welfare Measures of Services Liberalization in Simple CES Model to Inter-Temporal Discount Factors ( $\rho)$

4.1 Varying Only the Discount Factor $\left(\rho_{2}\right)$ in Country 2

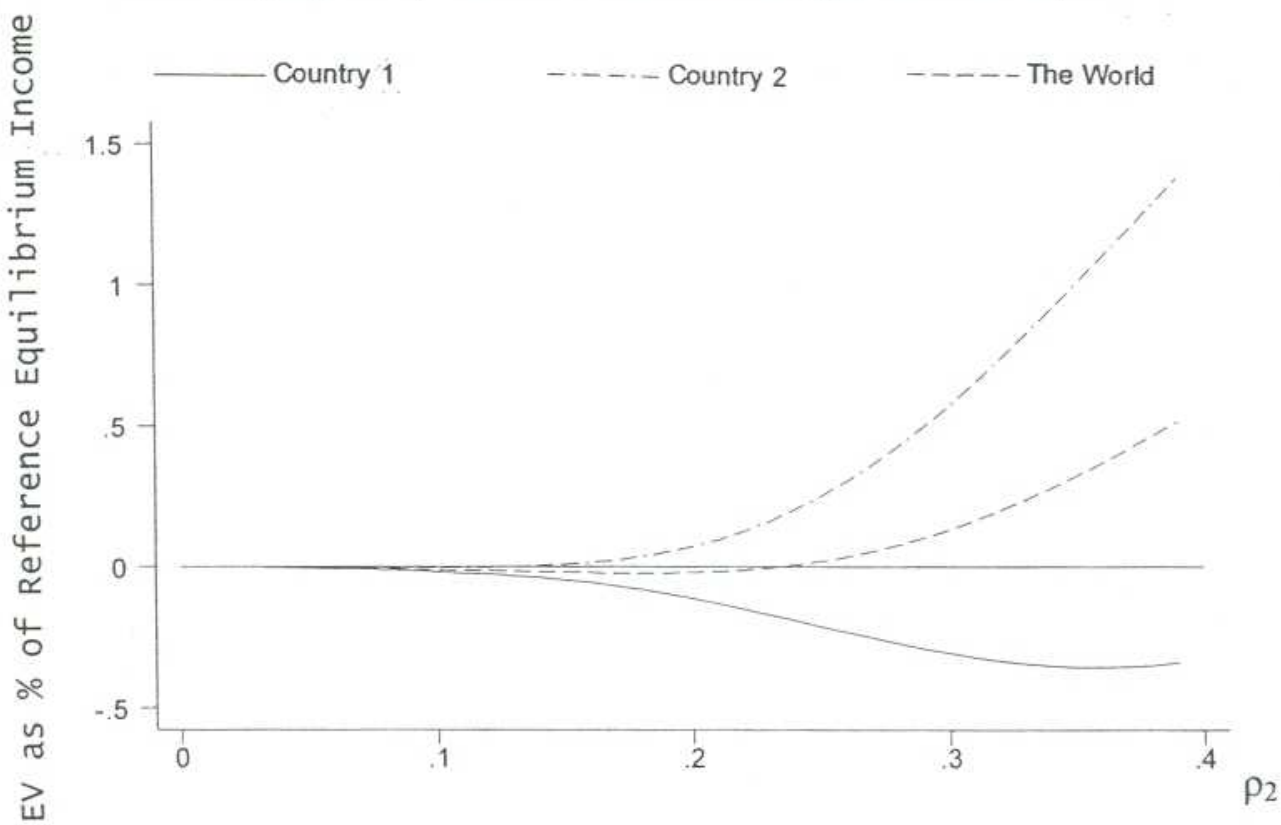

4.2 Varying the Discount Factor $\left(\rho_{1}=\rho_{2}\right)$ in Both Countries

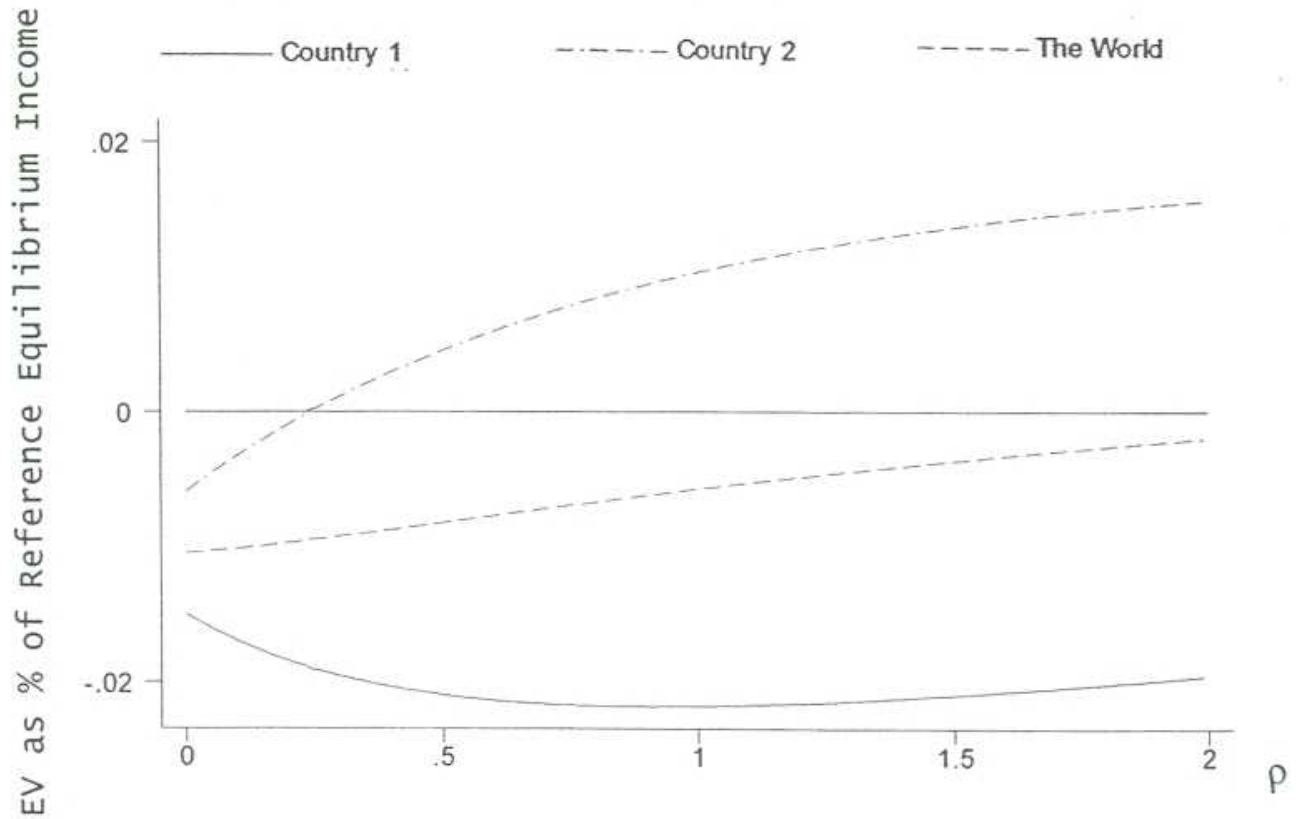




\title{
CESifo Working Paper Series
}

\author{
(for full list see www.cesifo.de)
}

1397 Marko Köthenbürger, Panu Poutvaara and Paola Profeta, Why are More Redistributive Social Security Systems Smaller? A Median Voter Approach, February 2005

1398 Gabrielle Demange, Free Choice of Unfunded Systems: A First Assessment, February 2005

1399 Carlos Fonseca Marinheiro, Sustainability of Portuguese Fiscal Policy in Historical Perspective, February 2005

1400 Roel M. W. J. Beetsma and Koen Vermeylen, The Effect of Monetary Unification on Public Debt and its Real Return, February 2005

1401 Frank Asche, Petter Osmundsen and Maria Sandsmark, Is It All Oil?, February 2005

1402 Giacomo Corneo, Media Capture in a Democracy: The Role of Wealth Concentration, February 2005

1403 A. Lans Bovenberg and Thijs Knaap, Ageing, Funded Pensions and the Dutch Economy, February 2005

1404 Thiess Büttner, The Incentive Effect of Fiscal Equalization Transfers on Tax Policy, February 2005

1405 Luisa Fuster, Ayşe İmrohoroğlu and Selahattin İmrohoroğlu, Personal Security Accounts and Mandatory Annuitization in a Dynastic Framework, February 2005

1406 Peter Claeys, Policy Mix and Debt Sustainability: Evidence from Fiscal Policy Rules, February 2005

1407 James M. Malcomson, Supplier Discretion over Provision: Theory and an Application to Medical Care, February 2005

1408 Thorvaldur Gylfason, Interview with Assar Lindbeck, February 2005

1409 Christian Gollier, Some Aspects of the Economics of Catastrophe Risk Insurance, February 2005

1410 Gebhard Kirchgässner, The Weak Rationality Principle in Economics, February 2005

1411 Carlos José Fonseca Marinheiro, Has the Stability and Growth Pact Stabilised? Evidence from a Panel of 12 European Countries and Some Implications for the Reform of the Pact, February 2005

1412 Petter Osmundsen, Frank Asche, Bård Misund and Klaus Mohn, Valuation of International Oil Companies -The RoACE Era, February 2005 
1413 Gil S. Epstein and Shmuel Nitzan, Lobbying and Compromise, February 2005

1414 Marcel F. M. Canoy, Jan C. van Ours and Frederick van der Ploeg, The Economics of Books, February 2005

1415 Eric A. Hanushek and Ludger Wößmann, Does Educational Tracking Affect Performance and Inequality? Differences-in-Differences Evidence across Countries, February 2005

1416 George Kapetanios and M. Hashem Pesaran, Alternative Approaches to Estimation and Inference in Large Multifactor Panels: Small Sample Results with an Application to Modelling of Asset Returns, February 2005

1417 Samuel Mühlemann, Jürg Schweri, Rainer Winkelmann and Stefan C. Wolter, A Structural Model of Demand for Apprentices. February 2005

1418 Giorgio Brunello and Lorenzo Rocco, Educational Standards in Private and Public Schools, February 2005

1419 Alex Bryson, Lorenzo Cappellari and Claudio Lucifora, Why so Unhappy? The Effects of Unionisation on Job Satisfaction, March 2005

1420 Annalisa Luporini, Relative Performance Evaluation in a Multi-Plant Firm, March 2005

1421 Giorgio Bellettini and Carlotta Berti Ceroni, When the Union Hurts the Workers: A Positive Analysis of Immigration Policy, March 2005

1422 Pieter Gautier, Michael Svarer and Coen Teulings, Marriage and the City, March 2005

1423 Ingrid Ott and Stephen J. Turnovsky, Excludable and Non-Excludable Public Inputs: Consequences for Economic Growth, March 2005

1424 Frederick van der Ploeg, Back to Keynes?, March 2005

1425 Stephane Dees, Filippo di Mauro, M. Hashem Pesaran and L. Vanessa Smith, Exploring the International Linkages of the Euro Area: a Global VAR Analysis, March 2005

1426 Hans Pitlik, Friedrich Schneider and Harald Strotmann, Legislative Malapportionment and the Politicization of Germany's Intergovernmental Transfer System, March 2005

1427 Konstantinos Angelopoulos and Apostolis Philippopoulos, The Role of Government in Anti-Social Redistributive Activities, March 2005

1428 Ansgar Belke and Daniel Gros, Asymmetries in the Trans-Atlantic Monetary Policy Relationship: Does the ECB follow the Fed?, March 2005

1429 Sören Blomquist and Luca Micheletto, Optimal Redistributive Taxation when Government's and Agents' Preferences Differ, March 2005 
1430 Olof Åslund and Peter Fredriksson, Ethnic Enclaves and Welfare Cultures - QuasiExperimental Evidence, March 2005

1431 Paul De Grauwe, Roberto Dieci and Marianna Grimaldi, Fundamental and NonFundamental Equilibria in the Foreign Exchange Market. A Behavioural Finance Framework, March 2005

1432 Peter Egger, Stefan Gruber, Mario Larch and Michael Pfaffermayr, Knowledge-Capital Meets New Economic Geography, March 2005

1433 George Economides and Apostolis Philippopoulos, Should Green Governments Give Priority to Environmental Policies over Growth-Enhancing Policies?, March 2005

1434 George W. Evans and Seppo Honkapohja, An Interview with Thomas J. Sargent, March 2005

1435 Helge Berger and Volker Nitsch, Zooming Out: The Trade Effect of the Euro in Historical Perspective, March 2005

1436 Marc-Andreas Muendler, Rational Information Choice in Financial Market Equilibrium, March 2005

1437 Martin Kolmar and Volker Meier, Intra-Generational Externalities and InterGenerational Transfers, March 2005

1438 M. Hashem Pesaran and Takashi Yamagata, Testing Slope Homogeneity in Large Panels, March 2005

1439 Gjermund Nese and Odd Rune Straume, Industry Concentration and Strategic Trade Policy in Successive Oligopoly, April 2005

1440 Tomer Blumkin and Efraim Sadka, A Case for Taxing Education, April 2005

1441 John Whalley, Globalization and Values, April 2005

1442 Denise L. Mauzerall, Babar Sultan, Namsoug Kim and David F. Bradford, Charging $\mathrm{NO}_{x}$ Emitters for Health Damages: An Exploratory Analysis, April 2005

1443 Britta Hamburg, Mathias Hoffmann and Joachim Keller, Consumption, Wealth and Business Cycles in Germany, April 2005

1444 Kohei Daido and Hideshi Itoh, The Pygmalion Effect: An Agency Model with Reference Dependent Preferences, April 2005

1445 John Whalley, Rationality, Irrationality and Economic Cognition, April 2005

1446 Henning Bohn, The Sustainability of Fiscal Policy in the United States, April 2005

1447 Torben M. Andersen, Is there a Role for an Active Fiscal Stabilization Policy? April 2005 
1448 Hans Gersbach and Hans Haller, Bargaining Power and Equilibrium Consumption, April 2005

1449 Jerome L. Stein, The Transition Economies: A NATREX Evaluation of Research, April 2005

1450 Raymond Riezman, John Whalley and Shunming Zhang, Metrics Capturing the Degree to which Individual Economies are Globalized, April 2005

1451 Romain Ranciere, Aaron Tornell and Frank Westermann, Systemic Crises and Growth, April 2005

1452 Plutarchos Sakellaris and Focco W. Vijselaar, Capital Quality Improvement and the Sources of Growth in the Euro Area, April 2005

1453 Kevin Milligan and Michael Smart, Regional Grants as Pork Barrel Politics, April 2005

1454 Panu Poutvaara and Andreas Wagener, To Draft or not to Draft? Efficiency, Generational Incidence, and Political Economy of Military Conscription, April 2005

1455 Maurice Kugler and Hillel Rapoport, Skilled Emigration, Business Networks and Foreign Direct Investment, April 2005

1456 Yin-Wong Cheung and Eiji Fujii, Cross-Country Relative Price Volatility: Effects of Market Structure, April 2005

1457 Margarita Katsimi and Thomas Moutos, Inequality and Relative Reliance on Tariffs: Theory and Evidence, April 2005

1458 Monika Bütler, Olivia Huguenin and Federica Teppa, Why Forcing People to Save for Retirement may Backfire, April 2005

1459 Jos Jansen, The Effects of Disclosure Regulation of an Innovative Firm, April 2005

1460 Helge Bennmarker, Kenneth Carling and Bertil Holmlund, Do Benefit Hikes Damage Job Finding? Evidence from Swedish Unemployment Insurance Reforms, May 2005

1461 Steffen Huck, Kai A. Konrad and Wieland Müller, Merger without Cost Advantages, May 2005

1462 Louis Eeckhoudt and Harris Schlesinger, Putting Risk in its Proper Place, May 2005

1463 Hui Huang, John Whalley and Shunming Zhang, Trade Liberalization in a Joint Spatial Inter-Temporal Trade Model, May 2005 